\title{
The Positive Impact of Rebranding to Increasing Consumer loyality with Brand Image as the Mediating Variable
}

\author{
Andre Prayoga ${ }^{*}$, Eko Suseno $^{2}$ \\ 1,2The Faculty of Economics and Business, Satya Wacana Christian University, Salatiga, Indonesia
}

\section{A R T I C L E I N F O}

Article history:

Received 31 August 2020

Received in revised form

5 September 2020

Accepted 18 October 2020

Available online 01

November 2020

Keywords:

Rebranding, Brand Image,

Loyalitas Konsumen

\begin{abstract}
A B S T R A C T
This study aims to analyze the effect of rebranding to consumer loyality with brand image as mediating variable. This research is using quantitative approach. 100 people of Gojek users are the sample, which were chosen with purposive sampling method. Data in this research were collected using questionnaire in Google Form as the instrument, then the data were analyzed using simple regression and Sobel test with the help of IBM SPSS Statistics application. The result shows that rebranding has positive effect fo consumer loyality; brand image has positive effect to consumer loyality; rebranding has positive effect to brand image. Besides, Sobel test result shows that the value of $\mathrm{t}$-count $<\mathrm{t}$-table $(1.248<1.984)$, so it can be concluded that brand image does not mediating the rebranding effect to consumer loyality for the Gojek users. The result of this research can be used as a suggestion for the marketings (especially for marketing or a company that is willing to do logo rebranding) to see how the effect of rebranding is to consumer loyality with brand image as the mediating variable.
\end{abstract}

Copyright (C) Universitas Pendidikan Ganesha. All rights reserved.

\section{Introduction}

Badan Pusat Statistik (Central Bureau of Statistics) recorded the total population in Indonesia, which reached 269.9 million people in 2019 (BPS, 2019). The total of active internet users according to We Are Social's data reached 150 million users or 56\% from the Indonesian total population (Riyanto, 2019). It was recorded that $96 \%$ of the total internet users in Indonesia have used e-commerce or doing online transactions, and Indonesia is one of the biggest internet users in Asia in 2019 (Solihin, 2020; Sudaryana et al., 2020). With the high number of e-commerce and internet users in Indonesia, it shows that the public is aware to technological change in recent days (Anwar, 2017; Kurniati, 2017). As an example, Gojek is on of the most used e-commerce in Indonesia.

Gojek is a Indonesian-origin company engaging online transportation service sector founded by Nadiem Makarim on 13 October 2010 with call-center booking as the main service. In 2015, Gojek launched an application with three main services, such as; GoSend, GoMart and GoRide. From these three main services, they are getting well-known by the public (Everlin \& Erlyana, 2020; Syafariansyah, 2018). Driver partners now have reached more than 2,000,000 partners, 400,000 merchant partners and 60,000 service providers in Southeast Asia. Along the way, Gojek has been rapidly growing and become the biggest technology group who serves millions of users in Southeast Asia. In 2019, the value of Gojek reaches USD 10 million, and was certified to bear decacorn status.

One of marketing strategies in changing the company image is rebranding or the change of brand (Miller et al., 2014; Rasyid \& Rizqina, 2019). A company that changes its name or logo will have a positive effect if the strategy, communication, product and service are consistent and in tune (Rosyada, 2018; Tjiptono, 2015). Rebranding strategy will make the company to be able to have a new concept, image and identity, and the company will also renew its repositioning to maintain the existing customers and to attrach new customers (Hanson et al., 2009). Nowadays, consumers are more aware to the brand information that is being offered by producers in a very open market competition (Chrisandi, 2014).

In the midst of competition, Gojek did a logo rebranding, exactly on 22 July 2019, which had been identical with motorcycle symbol, now Gojek has a new logo shaping like an upside down on/off button and was named Solv. One of the reasons to base the Gojek logo change was they would not only be recognized as a ride hailing service, but Gojek also wanted to be recognized as an super app with 20 
services that ease the users in their daily lives. The goal of this rebranding is to update and refresh the brand image and to recover a deficient brand image (Aspizain, 2014; Rasyid \& Rizqina, 2019).

This research uses rebranding as the independent variable and consumer loyality as the dependent variable. In the previous researches, as done by (Wiranata \& Yuldinawati, 2014)) on Fourspeed Nomad as the object, got a positive result that rebranding has a significant effect on consumer loyality , then on (Sucipto, 2018) research on celebrity fitness in Puri Indah Mall, shows a positive result that rebranding significantly affecting the brand image, and in (Winata \& Andjarwati, 2018)) on PO Sugeng Rahayu as the object, got a result that rebranding positively affecting the brand image and significant change in consumer loyality. Meanwhile, in (Sufiatno, 2016) research with Frisian Flag as the object, found a negative result, that rebranding does not affect consumer loyality. The previous research was done by (Kaihatu, 2012; Thomas, 2016; Winata \& Andjarwati, 2018) using brand image variable as the mediating variable.

Reinvestigation and replication about rebranding is done based on research by (Winata \& Andjarwati, 2018) because there is a different result with the research done by (Sufiatno, 2016), which got a negative result that rebranding does not affect the Frisian Flag consumer loyality, then an interest emerged to study about rebranding and to bring up a new phenomenon, which was Gojek that changed its logo or so-called "rebranding".

Based on research by (Winata \& Andjarwati, 2018), this research is also using brand image as the mediating variable because it is believed that it strengthens the connection between rebranding and consumer loyality indirectly, which is supported by (Schiffman \& Kanuk, 2008) theory saying that a positive brand image will have a strong bond with loyality in buying products, having trust and thinking positive values to find that particular brand. Then it is supported by (Thomas, 2016) research saying that brand image as mediating variable could strengthen the effect of rebranding to consumer loyality, and according to (Maunaza, 2012), a good brand image, emotionally will make a satisfaction for consumers that give impression to a brand, which leads to continuous buying.

The goal of this research is to analyze the effect of rebranding to the brand image, to analyze the effect of brand image to consumer loyality, to analyze the effect of rebranding to consumer loyality and to analyze the effect of brand image as the mediating variable between rebranding and consumer loyality of Gojek users in Salatiga.

\section{Method}

The method used in this research is quantitative research with formulating hypothesis method first in form of interrogative sentences, and then continued by using statistical calculation to know whether the proposed hypothesis could be denied or accepted based on the existing data (Hidayat \& Firdaus, 2014). The data source for this research is the primary data. Primary data means that the data were taken from questionnaire result from active consumers using Gojek as the respondent.

For every variable, the definition is taken from multiple sources written in Table 1.

Table 1. Operational Variable Definition

\begin{tabular}{|c|c|c|}
\hline Variable dan Variable Definition & Dimension & Indicator \\
\hline $\begin{array}{l}\text { Rebranding } \\
\text { An act done twice to create a new name, } \\
\text { symbol, term, tag line, and design that } \\
\text { represents the change of stakeholders' } \\
\text { paradigm and differentiates the identity with } \\
\text { the competitors (Muzellec \& Lambkin, 2006; } \\
\text { Winata \& Andjarwati, 2018). }\end{array}$ & $\begin{array}{ll}\text { 1. } & \text { Repositioning } \\
\text { 2. } & \text { Renaming } \\
\text { 3. } & \text { Redesign } \\
\text { 4. } & \text { Relaunching }\end{array}$ & $\begin{array}{l}\text { 1. } \begin{array}{l}\text { Consumer knows } \\
\text { Gojek logo change } \\
\text { 2. Gojek logo change } \\
\text { gives new } \\
\text { characteristic } \\
\text { Gojek new logo seems } \\
\text { more elegant and } \\
\text { attractive }\end{array} \\
\text { 4. Gojek new logo is easy } \\
\text { to remember and up to } \\
\text { date }\end{array}$ \\
\hline
\end{tabular}




\begin{tabular}{|c|c|c|}
\hline Variable dan Variable Definition & Dimension & Indicator \\
\hline $\begin{array}{l}\text { Brand Image } \\
\text { How the actual point of view of a brand by } \\
\text { the consumers (Kotler \& Keller, 2009; } \\
\text { Maharani, 2020). }\end{array}$ & 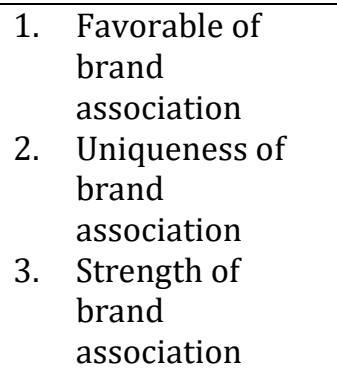 & $\begin{array}{l}\text { 1. } \begin{array}{l}\text { Explaining products or } \\
\text { service (innovative) }\end{array} \\
\text { 2. Having a unique } \\
\text { characteristic } \\
\text { 3. Giving positive value } \\
\text { 4. Reflecting the identity } \\
\text { of product or service }\end{array}$ \\
\hline $\begin{array}{l}\text { Consumer Loyality } \\
\text { Positive consumers commitment for a long- } \\
\text { term buying to a store or brand (Dasuki, } \\
\text { 2017; Griffin, 2005; Tjiptono, 2002). }\end{array}$ & $\begin{array}{ll}\text { 1. } & \text { Premium loyality } \\
\text { 2. Hidden loyality } \\
\text { 3. Weak loyality } \\
\text { 4. No loyality }\end{array}$ & 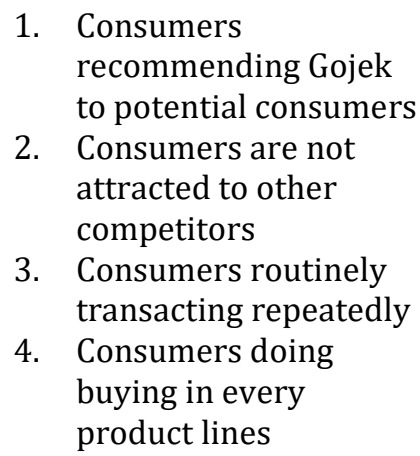 \\
\hline
\end{tabular}

This research is using purposive sampling technique, where the sampling is done by setting a specific criterion that corresponds the goal of this research (Fianto et al., 2014). This research using Google Form as the data-collecting media which was done in Salatiga, this method is used because of the place and time limitations of COVID-19 that forces the online-based research to be done. The population in this research is Gojek actie users, including active transaction via Gojek application. Sample in this research is Gojek active users with criteria; as a user minimum or more than 1 year, doing active transaction twice a week using Gojek application, users who are transacting after Gojek made a rebranding and users who know the Gojek logo change. The amount of sample in this research is 100 respondents.

In this research, questionnaire is used as the data-collecting method; the questionnaires are spreaded to respondent who qualifies the criteria. Questionnaire is written in interrogative sentences in Likert scale, with the answer scale as follows; Sangat Tidak Setuju or Completely Disagree (1), Tidak Setuju or Disagree (2), Netral or Neutral (3), Setuju or Agree (4), Sangat Setuju or Completely Agree (5) (Fristiana et al., 2012).

To verify the hypothesis proposed, then the validity and reliability test to know whether the questionnaire is valid or not (Rusman, 2016). Then, classic assumption test is done using SPSS 26 software program. The classic assumption test includes normality test, to find out the normal or abnormal data frequency distribution, then heteroscedasticity test to find out variant uncomfortness in a regression model from residual in one to another observation, then multicolinearity test to find out whether there is correlation between independent variable and dependent variable in regression model, and linearity test to know whether the specification of a model is valid or not (Ghozali, 2018).

Afterwards, to test the effect of mediating variable, simple regression analyses are done first, and then analyze the path using Online Sobel Test. In simple regression analysis, the connections between variables are linear, where the change of $\mathrm{X}$ variables will be followed by Y variable constantly, meanwhile, path analysis with sobel test is done to test the effect of mediating variable (Pratama, 2015).

After that, Determination Coefficient test ( $R$ Square) is done, aiming to test gooness-fit from the model of a regressin, then there is Simultant Test ( $F$ test) to know the effect of all the independent variables altogether / simultant with the dependent variables, and then Partial Test / T Test to show how far is one variable to another (Manik \& Syafrina, 2018). 


\section{Results and Discussions}

\section{Results}

Table 2. Respondent Characteristics Distribution

\begin{tabular}{|c|c|c|c|}
\hline Responden Characteristic & & Frequency & Percentage \\
\hline \multirow[t]{6}{*}{ Age } & $<17$ Years old & 1 & $1 \%$ \\
\hline & 18-25 Years old & 95 & $95 \%$ \\
\hline & 26-35 Years old & 1 & $1 \%$ \\
\hline & 36-45 Years old & 2 & $2 \%$ \\
\hline & $>46$ Years old & 1 & $1 \%$ \\
\hline & TOTAL & 100 & $100 \%$ \\
\hline \multirow[t]{3}{*}{ Gender } & Male & 52 & $52 \%$ \\
\hline & Female & 48 & $48 \%$ \\
\hline & TOTAL & 100 & $100 \%$ \\
\hline \multirow[t]{6}{*}{ Job } & Students & 84 & $84 \%$ \\
\hline & Entrepreneur & 6 & $6 \%$ \\
\hline & Employee & 9 & $9 \%$ \\
\hline & State Civil Apparatus & 0 & $0 \%$ \\
\hline & Housewife & 1 & $1 \%$ \\
\hline & TOTAL & 100 & $100 \%$ \\
\hline \multirow[t]{3}{*}{ Having Gojek Application } & Yes & 100 & $100 \%$ \\
\hline & No & 0 & $0 \%$ \\
\hline & TOTAL & 100 & $100 \%$ \\
\hline \multirow[t]{3}{*}{ Knowing Gojek Logo Change } & Yes & 100 & $100 \%$ \\
\hline & No & 0 & $0 \%$ \\
\hline & TOTAL & 100 & $100 \%$ \\
\hline \multirow[t]{5}{*}{ Transaction using Gojek in a week } & 0-1 Times & 0 & $0 \%$ \\
\hline & 2-3 Times & 88 & $88 \%$ \\
\hline & 4-5 Times & 7 & $7 \%$ \\
\hline & $>6$ Times & 5 & $5 \%$ \\
\hline & TOTAL & 100 & $100 \%$ \\
\hline
\end{tabular}

From the data in the above table, it shows that all respondents are certified for sampling. The most respondent is in the age range of $18-25$, as much as $95 \%$. Male as much as 52 men, or $52 \%$, and Students are dominating the respondents, as much as $88 \%$ doing transaction 2-3 times in a week.

Hypothesis Test

Rebranding towards Brand Image

$\underline{\text { Table 3. Regression Test } 1 \text { Result }}$

\begin{tabular}{|c|c|c|c|c|}
\hline \multicolumn{5}{|c|}{ Coefficients } \\
\hline \multirow[t]{2}{*}{ Model } & \multicolumn{2}{|c|}{ Unstandardized Coefficients } & \multirow[t]{2}{*}{$\mathbf{t}$} & \multirow[t]{2}{*}{ Sig. } \\
\hline & B & Std. Error & & \\
\hline (Constant) & 4.926 & 1.544 & 3.191 & .002 \\
\hline rebranding & .455 & .061 & 7.451 & .000 \\
\hline
\end{tabular}

$$
\mathrm{Y}=4.926+0.455 \mathrm{X}+\mathrm{e}
$$

Based on simple linear regression equation, the result of regression coefficient is 4.926 , which means if rebranding variable $(\mathrm{X})$ is 0 , then the brand image variable (Z) will still be 4.926 and every increment one unit in rebranding variable, it will increase brand image as much as 0.455 units. 


\section{Brand Image towards Consumer Loyality}

Table 4. Regression Test 2 Result

\begin{tabular}{|c|c|c|c|c|}
\hline \multirow[t]{2}{*}{ Model } & \multicolumn{2}{|c|}{ Unstandardized Coefficients } & \multirow[t]{2}{*}{$\mathbf{t}$} & \multirow[t]{2}{*}{ Sig. } \\
\hline & B & Std. Error & & \\
\hline (Constant) & 8.906 & 1.908 & 4.669 & .000 \\
\hline brand image & .385 & .115 & 3.338 & .001 \\
\hline
\end{tabular}

$$
\mathrm{Y}=8.906+0.385 \mathrm{Z}+\mathrm{e}
$$

Based on simple linear regression equation, the result of regression coefficient is 8.906 which means if rebranding variable $(\mathrm{X})$ is 0 , then the consumer loyality variable $(\mathrm{Y})$ will still be 8.906 and every increment one unit in rebranding variable, it will increase brand image as much as 0.385 units.

\section{Rebranding towards Consumer Loyality}

Table 5. Regression Test 3 Result

\begin{tabular}{llcccccc}
\hline \multirow{2}{*}{ Model } & \multicolumn{2}{c}{ Unstandardized Coefficients } & Standardized Coefficients & \multirow{2}{*}{ t } & \multirow{2}{*}{ Sig. } \\
\cline { 3 - 5 } & & B & Std. Error & Beta & 3.078 & .003 \\
\multirow{2}{*}{1} & (Constant) & 6.640 & 2.157 & & & \\
& rebranding & .341 & .085 & .375 & 4.003 & .000 \\
\hline
\end{tabular}

$$
Y=6,640+0,341 X+e
$$

Based on simple linear regression equation, the result of regression coefficient is 6.640 , which means if rebranding variable $(\mathrm{X})$ is 0 , then the consumer loyality variable $(\mathrm{Y})$ will still be 6.640 and every increment one unit in rebranding variable, it will increase consumer loyality as much as 0.341 units.

\section{Determination Coefficient Test \\ Rebranding towards Brand Image}

Based on R Square test result on rebranding towards brand image, the value of R Square from this regression model is 0.362 . The competence of independent variable in explaining the variants of dependent variable is $36.2 \%$. This means that there are $63.8 \%$ variants of variable that is being explained by other variables outside the research.

\section{Brand Image towards Consumer Loyality}

Based on R Square test result on brand image towards consumer loyality, the value of R Square from this regression model is 0.102 . The competence of independent variable in explaining the variants of dependent variable is $10.2 \%$. This means that there are $89.8 \%$ variants of variable that is being explained by other variables outside the research.

\section{Rebranding towards Consumer Loyality}

Based on R Square test result on rebranding towards consumer loyality, the value of R Square from this regression model is 0.141 . The competence of independent variable in explaining the variants of dependent variable is $14.1 \%$. This means that there are $85.9 \%$ variants of variable that is being explained by other variables outside the research.

\section{Rebranding and Brand Image towards Consumer Loyality}

Based on R Square test result on rebranding towards consumer loyality, the value of R Square from this regression model is 0.154 . The competence of independent variable in explaining the variants of dependent variable is $84.6 \%$. This means that there are $84.6 \%$ variants of variable that is being explained by other variables outside the research.

\section{F Test Result}

F Test or so-called simultaneous test/model test/anova test, is a test to know the effect all of the independent variable simultaneously to their dependent variable. From statistic test result above, Sig. F 
value is 0.000 , less than alpha 0.05 , can be concluded that rebranding and brand image variable are strongly affecting the consumer loyality simultaneously.

\title{
T Test Result
}

From linear regression result analysis, with comparing the value of Sig. from each variable with the alpha value is 0.05 , if the analysis Sig. result is less than 0.05 then the hypothesis will be accepted, but if it is more than 0.05 , the hypothesis is denied.

Rebranding variable has positive effect on brand image variable because the significancy value is 0.000 so that is's less than 0.05 . So, the first hypothesis, $\mathrm{H}_{1}$ : Rebranding has positive effect towards brand image is accepted. Brand image variable has positive effect on consumer loyality variable because the significancy value is 0.001 , so that this is less than alpha 0.05 . So, the second hypothesis, $\mathrm{H}_{2}$ : Brand image has positive effect towards consumer loyality is accepted. Rebranding variable has positive effect on consumer loyality variable because the significancy value is 0.000 , so that this is less than alpha 0.05 . So, the third hypothesis, $\mathrm{H}_{3}$ : Rebranding has positive effect on consumer loyality is accepted.

\section{Sobel Test Result}

Mediating hypothesis testing can be done with procedures developed by Sobel and is known as Sobel Test. Sobel test is done by testing the indirect effect strength of $X$ to $Z$, through $Y$. Indirect effet of $X$ to Z through Y is calculated by shifting X-Y line (a) with Y-Z line (b) or $a b$ path. So the coefficient of $a b=\left(c^{\prime}\right.$ - c), where the $c$ is the effect of $X$ towards $Z$ withouth controlling $Y$, meanwhile the $c^{\prime}$ is the effect coefficient of X towards Z after controlling Y (Sarwono, 2010).

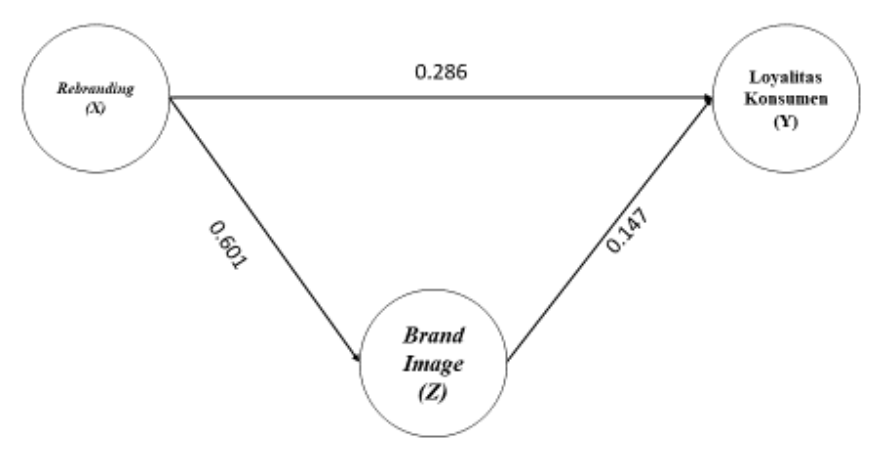

Figure 1. Sobel Test Result

\author{
Direct Effect \\ $\mathrm{X} \rightarrow \mathrm{Z}=0.601$ \\ $\mathrm{Z} \rightarrow \mathrm{Y}=0.147$ \\ $\mathrm{X} \rightarrow \mathrm{Y}=0.286$ \\ Indirect Effect \\ $\mathrm{X} \rightarrow \mathrm{Z} \rightarrow \mathrm{Y}=0.088$ \\ Total Effect \\ $\mathrm{X} \rightarrow \mathrm{Z} \rightarrow \mathrm{Y}=0.601+0.147=0.748$
}

From calculation formula, the value of count $t$ is 1.24471027 and the value of table $t$ is 1.984 . Based on this result, it can be concluded that this research has no mediating effect by brand image variable between rebranding variable and consumer loyality variable.

\section{Discussions}

Based on statistical test result, rebranding variable has positive effect on brand image variable with 0.000 value of probability, so this value is less than alpha 0.05 . This result is supported by previous research having the result of rebranding variable has positive effect on brand image variable (Rosyada, 2018; Sucipto, 2018; Wardani \& Wibowo, 2017; Winata \& Andjarwati, 2018).

This matter shows that rebranding by Gojek management affecting Gojek's brand image. This is because rebranding is one of the strategies done to create a positive image for a brand to the perception by the consumers. Can be seen from the average anwers in rebranding variable that showing "Knowing Gojek Logo Change" is categorized as "Very High" with mean value of 4.5 and "Gojek new logo seems more 
elegant and attractive" is "Very High" with mean value of 4.26. This means that people who use Gojek application admit that when Gojek changed its logo, the brand image from Gojek brand seems better and makes Gojek having a unique logo and characteristics. People also realize that Gojek logo seems more elegant and this is what makes Gojek consumers judging Gojek made its brand image better through the logo change.

Then the statistical test result on brand image variable, has positive effect on consumer loyality variable with 0.001 , so the amount is less than alpha 0.05 . The result of this research is in accordance with the previous researches that also showing brand image having a positive effect on consumer loyality (Wijayanto, 2013; Winata \& Andjarwati, 2018). It can be seen in the respondents' answers on brand image indicator showing a high average with mean value of 4.19 in "New logo give a unique characteristic from Gojek product services (logo design or shape)", which means that when Gojek changed their logo, people evaluated that Gojek new logo gave a distinct identity from Gojek product services (Maharani, 2020). Gojek new logo also felt to give a positive aspect to Gojek product services from the perspective of Gojek users. Consumer also agrees that Gojek logo change can also show a more innovative service from Gojek. From this statement, we could conclude that the better a brand image is, the higher the consumer loyality to that product. Brand image made by Gojek from logo change could give its consumers to be loyal to the services inside the Gojek application (Everlin \& Erlyana, 2020).

As well as the statistical test result on rebranding variable that shows a positive effect on consumer loyality variable with 0.000 probability score, less than alpha 0.05 . The result is supporting the research done by (Winata \& Andjarwati, 2018; Wiranata \& Yuldinawati, 2014) which stated that rebranding has a positive effect on consumer loyality. It can be seen on the respondents' answer with mean value of 4.29, which is categorized as Sangat Tinggi (Very High) on the statement "Consumer knows Gojek logo change" and "Gojek new logo seems more elegant and attractive" with 4.2 mean value, categorized as Sangat Tinggi (Very High), means that Gojek consumer loyality shows when Gojek changed its logo. Consumer knows that Gojek made a logo change and they are still loyal to Gojek. Consumer also agrees that Gojek logo seems more elegant, so that they are attracted to the new logo and showing their loyality to Gojek as a consumer.

However, on the Sobel Test result, it shows the value of count $t<$ table $t$ as much as $1.244<1.984$. With this result, it is stated that brand image does not mediating the effect of rebranding to Gojek consumer loyality. Rebranding of Gojek logo is affecting Gojek consumers directly without brand image, because consumer will still be loyal to Gojek because they assume if using Gojek application will ease them in fulfilling their needs even with the logo change. But in this matter, Gojek management has succeed to do rebranding even if the brand image's role does not mediate between the rebranding and consumer loyality of Gojek in Salatiga.

The result of this research could be used as the suggestion for the marketing-person (for seller or a company willing to do logo rebranding) to see how the effect is of rebranding to consumer loyality through brand image as the mediating variable. It is suggested that the marketing or the company to try to elevate the brand image from a brand, so to have a big impact on consumer loyality of a brand, and this research can also be used as an addition to the literature of rebranding, brand image and consumer loyality, especially for Gojek.

\section{Conclusion}

This research proves that there is positive impact from brand image to Gojek users in Salatiga, and then positive impact from brand image to Gojek consumer loyality in Salatiga, and also the positive effect on rebranding to Gojek consumer loyality in Salatiga. But in this research, brand image's role as mediating variable was proven to not mediating the rebranding and consumer loyality. Gojek logo rebranding affects Gojek consumers directly without brand image, because they will still be loyal, assuming that Gojek application will still ease them to fulfill their needs even with the logo change on Gojek, and without looking at the image of Gojek itself.

\section{References}

Anwar, A. A. (2017). Online vs Konvensional: Keunggulan dan Konflik Antar Moda Transportasi di Kota Makassar. Etnosia: Jurnal Etnografi Indonesia, 2(2), 220-246. https://doi.org/10.31947/etnosia.v2i2.3012

Aspizain, C. (2014). The Effect Of Service Quality Of Corporate Rebranding On Brand Image, Customer Satisfication, Brand Equity and Costomer Loyalty. Russian Journal of Agricultural and SocioEconomic, 6(3), 120-132. https://cyberleninka.ru/article/n/the-effects-of-service-quality-and- 
corporate-rebranding-on-brand-image-customer-satisfaction-brand-equity-and-customer-loyaltystudy-in

BPS. (2019). Jumlah Penduduk Indonesia Menurut Kelompok Umur dan Jenis Kelamin. Badan Pusat Statistik.

Chrisandi, N. P. (2014). Hubungan Citra Merek dan Kualitas Pelanggan dengan Loyalitas Pelanggan Produk Apple. Calyptra, $3(1)$,

1-11.

http://webhosting.ubaya.ac.id/ journalubayaac/index.php/jimus/article/view/1515

Dasuki, H. (2017). Pengaruh Corporate Rebranding Terhadap Loyalitas Konsumen PT. EIGER Melalui Brand Association dan Reputasi Perusahaan (Studi pada UKM Pencinta Alam di Bandar Lampung) [Universitas Negeri Lampung]. http://digilib.unila.ac.id/28228/

Everlin, S., \& Erlyana, Y. (2020). Analisis Perubahan Desain Logo Gojek Tahun 2019. DESKOMVIS: Jurnal Ilmiah Komunikasi Visual, Seni Rupa Dan Media, 1(1), 72-88. https://doi.org/10.38010/dkv.v1i1.11

Fianto, A. Y., Hadiwidjojo, D., \& Aisjah, S. (2014). The Influence of Brand Image on Purchase Behaviour Through Brand Trust. Journal of Business Management and Strategy, 5(2), 58-66. http://www.academia.edu/download/50315848/6003-22562-1-PB.pdf

Fristiana, D. A., Prihatini, A. E., \& Listyorini, S. (2012). Pengaruh Citra Merek dan Harga terhadap Keputusan Pembelian pada Ramai Swalayan Peterongan Semarang. JIAB: Jurnal Ilmu Administrasi Bisnis, 1(2), 118-127. https://ejournal3.undip.ac.id/index.php/jiab/article/view/839

Ghozali, I. (2018). Aplikasi Analisis Multivariate dengan Program IBM SPSS 25 (9th editio). Badan Penerbit Universitas Diponegoro.

Griffin, J. (2005). Customer Loyalty : Menumbuhkan dan Mempertahankan Kesetiaan Pelanggan. Erlangga.

Hanson, B., Mattila, A. S., \& O’Neilll, J. W. (2009). Hotel Rebranding and Rescaling: Effects on Financial Performance. Cornell Hospitality Quarterly Journals, 50(3), 360-370. https://doi.org/10.1177/1938965509332762

Hidayat, D. R., \& Firdaus, M. R. (2014). Analisis Pengaruh Kualitas Layanan, Harga, Kepercayaan, Citra Perusahaan, Dan Kepuasan Pelanggan Terhadap Loyalitas Pelanggan (Studi Pada Pelanggan Telkom Speedy Di Palangka Raya). JWM: Jurnal Wawasan Manajemen, 2(3), 237-250. https://doi.org/10.20527/jwm.v2i3.16

Kaihatu, T. S. (2012). Kepuasan Konsumen yang Dipengaruhi oleh Kualitas Layanan dengan Brand Image Sebagai Variabel Perantara: Studi Kasus pada Konsumen Rumah Sakit Swasta di Kota Surabaya. Jurnal Mitra Ekonomi Dan Manajemen Bisnis, 3(2), 200-210. http://repository.petra.ac.id/16666/

Kotler, P., \& Keller, K. L. (2009). Manajemen Pemasaran (13th ed.). Erlangga.

Kurniati, A. W. (2017). Komunikasi Pemasaran Transportasi Online NGuberJEK. Jurnal Komunikasi Dan Kajian Media Vol.1, 1(1), 69-85. https://doi.org/10.31002/jkkm.v1i1.392

Maharani, S. (2020). Analisis Pengaruh Perubahan Logo dan Slogan (Rebranding) Terhadap Brand Image GOJEK [Universitas https://library.universitaspertamina.ac.id//xmlui/handle/123456789/1156

Pertamina].

Manik, S., \& Syafrina, N. (2018). Pengaruh Kompetensi Terhadap Kinerja Dosen Sekolah Tinggi Ilmu Ekonomi Riau. Jurnal Ilmiah Ekonomi Dan Bisnis, 15(1), 1-6. https://doi.org/10.31849/jieb.v15i1.72

Maunaza, A. (2012). Pengaruh Brand Image Terhadap Minat Membeli Konsumen (Studi Pada Penerbangan Lion Air Sebagai Low Cost Carrier) [Universitas Indonesia]. In Skripsi. http://152.118.24.168/detail?id=20308440\&lokasi=lokal

Miller, D., Merrilees, B., \& Yakimova, R. (2014). Corporate Rebranding: An Integrative Review of Major Enablers and Barriers to the Rebranding Process. International Journal of Management Reviews, 16(3). https://doi.org/10.1111/ijmr.12020

Muzellec, L., \& Lambkin, M. (2006). Corporate Rebranding: Destroying, Transferring or Creating Brand Equity? European Journal of Marketing, 40(7/8), 803-824. https://doi.org/10.1108/03090560610670007

Pratama, M. I. (2015). Pengaruh Rebranding Terhadap Citra Bank Jambi Pada Nasabah. Jurnal Kajian Komunikasi, 3(2), 140-156. https://doi.org/10.24198/jkk.v3i2.7404

Rasyid, R. A., \& Rizqina, R. (2019). Analisa Rebranding Terhadap Brand Association Dengan Brand Image Sebagai Mediasi Terhadap Brand Loyalty Pada Konsumen Gojek Surabaya. Jurnal Ecopreneur.12, 2(2), 1-6. https://doi.org/10.2345/e12.v2i2.495 
Riyanto, A. (2019). Hootsuite (We Are Social): Indonesian Digital Report. Global Digital Insights, 77. https://datareportal.com/reports/digital-2019-indonesia

Rosyada, A. (2018). Pengaruh Rebranding dan Kualitas Layanan Terhadap Citra Perusahaan Pada XL AXIATA (Studi pada Pengguna Simcard XL di XL Center Pemuda Surabaya). Jurnal Ilmu Manajemen (JIM), 6(1), 1-7. https://jurnalmahasiswa.unesa.ac.id/index.php/jim/article/view/22569

Rusman, T. (2016). Statistik Penelitian dengan Aplikasi SPPS. Graha Ilmu.

Sarwono, J. (2010). Path Analisis dengan SPSS: Teori, Aplikasi, Prosedur Analisis untuk Riset Skipsi, Tesis, Disertasi. Gramedia.

Schiffman, L., \& Kanuk, L. L. (2008). Perilaku Konsumen (7th ed.). PT. Indeks.

Solihin, D. (2020). Pengaruh Kepercayaan Pelanggan Dan Promosi Terhadap Keputusan Pembelian Konsumen Pada Online Shop Mikaylaku Dengan Minat Beli Sebagai Variabel Intervening. Jurnal MANDIRI: Ilmu Pengetahuan, Seni, Dan Teknologi, 4(1), 38-51. https://doi.org/10.33753/mandiri.v4i1.99

Sucipto, G. (2018). Pengaruh Rebranding Terhadap Brand Image Celebrity Fitness (Survey pada Pelanggan Mahasiswa di Celebrity Fitness Puri Indah Mall) [Universitas Multimedia Nusantara]. https://kc.umn.ac.id/5900/

Sudaryana, Y., Marjohan, M., Nufus, K., Andriani, J., \& Maswarni, M. (2020). Bimbingan Teknis Manajemen Peningkatan Penjualan Melalui E-Commerce Kepada Ikm/Umkm Koperasi Patih Di Kelurahan Cempaka Putih Kecamatan Ciputat Kota Tangerang Selatan Provinsi Banten. Jurnal Pengabdian Dharma Laksana, 3(1), 51. https://doi.org/10.32493/j.pdl.v3i1.6281

Sufiatno, F. (2016). Analisis Pengaruh Brand Logo Subtitution Terhadap Brand Loyalty Frisian Flag. Jurnal Bisnis Dan Manajemen, 53(12), 48-69. https://journal.untar.ac.id/index.php/bm/article/view/735

Syafariansyah, R. (2018). The Impact of Online Transportation Socio-Economy, in Samarinda. Jurnal Ekonomika: Manajemen, Akuntansi, Dan Perbankan Syari'ah, 7(2), 104-116. https://doi.org/10.24903/je.v7i2.449

Thomas, J. F. (2016). Analisa Pengaruh Rebranding Terhadap Brand Association Dengan Brand Image Sebagai Variabel Intervening Terhadap Customer Loyalty Pada PT Telkom Indihome Surabaya. Jurnal Strategi Pemasaran, 3(2), 1-10. http://publication.petra.ac.id/index.php/manajemenpemasaran/article/view/4438

Tjiptono, F. (2002). Prinsip \& Dinamika Pemasaran (1st ed.). J \& J Learning.

Tjiptono, F. (2015). Strategi Pemasaran (4th ed.). Andi Offset.

Wardani, T. A. P., \& Wibowo, S. (2017). The Influence of Rebranding Toward Brand Image of Indosat Ooredoo (Study on Im3 Ooredoo Users in Bandung City). Proceedings of Management, 4(1), 635-641.

Wijayanto, I. (2013). Pengaruh Citra Merek Terhadap Loyalitas Konsumen. Jurnal Ilmu Manajemen (JIM), 1(3), 910-918. https://jurnalmahasiswa.unesa.ac.id/index.php/jim/article/view/4557

Winata, D. H., \& Andjarwati, A. L. (2018). Pengaruh Rebranding Terhadap Loyalitas Dengan Citra Merek Sebagai Variabel Mediasi (Studi Pada Po Sugeng Rahayu). Jurnal Ilmu Manajemen (JIM), 7(2), 327333. https://jurnalmahasiswa.unesa.ac.id/index.php/jim/article/view/26105

Wiranata, A., \& Yuldinawati, L. (2014). Pengaruh Rebranding Terhadap Loyalitas Konsumen (Studi Kasus Fourspeed Nomad Di Kota Bandung 2014). Proceedings of Management, 10(1). 